\title{
PENGARUH EXTERNALITAS PADA STUKTUR BIAYA PRODUKSI BIODIESEL MIKROALGA SEBAGAI SUMBER ENERGI RAMAH LINGKUNGAN
}

\section{Effect for Externalities Costs Structure of Microalgae Biodiesel Production as a Source of Environmental Friendly Energy}

\author{
Arif Dwi Santoso, Tresna P. Soemardi, Kardono and Awal Subandar \\ Pusat Teknologi Lingkungan, Badan Pengkajian dan Penerapan Teknologi \\ Gedung Geostech 820, Puspiptek Serpong Banten 15314, Indonesia \\ E-mail: arif.dwisantoso@bppt.go.id
}

Diterima: 29 Juni 2013; Dikoreksi: 21 Juli 2013; Disetujui: 09 Agustus 2013

\begin{abstract}
This research was aimed to introduce microalgae biomass as an environmentally sustainable alternative biodiesel raw material. Comparation of all production cost variables between microalgae and oil palm biodiesel using production process cycle analysis system of extended life cycle analysis (extended LCA) was conducted. The use of extended LCA system could possibly accommodate all environmental commodity variables on biodiesel production. The potential of microalgae biomass as a renewable, low in the land use and environmentally sustainable material could be promoted. Environmental commodity variable values were estimated by willingness to pay (WTP)'s approach based on the Environmental Priority Strategy (EPS)'s ver. 2000 software calculations. The results showed there was an increase of biodiesel production cost of microalgae and oil palm after the inclusion of their externality variables cost. The highest biodiesel production cost was from the fresh fruit bunch biomass production of oil palm (49-64\%) of the total cost. Extended LCA analysis concluded that the increase of microalgae and oil palm biodiesel production cost was about 2.6 and $17.7 \%$, respectively. It can be indicated that biomass input for the production of biodiesel from microalgae is more environmentally sustainable than from oil palm because both technical and non -technical constraints during microalgae biomass production are easier to be solved. In addition, the microalgae will have a significant contribution in the green house gases (GHGs) mitigation by replacing fossil fuel in the future through its role as a biodiesel.
\end{abstract}

Keywords: microalgae, biodiesel, environmental commodity, production cost, life cycle analysis.

\begin{abstract}
Abstrak
Penelitian ini bertujuan untuk memperkenalkan biomassa mikroalga sebagai bahan baku biodiesel alternatif yang ramah lingkungan. Perbandingan semua variabel biaya produksi antara mikroalga dan biodiesel kelapa sawit menggunakan proses produksi sistem analisis siklus analisis siklus hidup diperpanjang (extended LCA) di evaluasi. Penggunaan sistem extended LCA dapat mencakupi semua variabel komoditas lingkungan sehingga potensi biomassa mikroalga sebagai material yang terbarukan, rendah dalam penggunaan lahan dan berkelanjutan dapat dipromosikan. Nilai -nilai variabel komoditas lingkungan diperkirakan melalui pendekatan kesediaan membayar (WTP) menggunakan perangkat lunak yang di kembangkan oleh Strategi Prioritas Lingkungan (EPS). Hasil penelitian menunjukkan bahwa ada peningkatan biaya produksi biodiesel dari mikroalga dan minyak sawit setelah dimasukkannya biaya variabel eksternalitas nya. Biaya produksi biodiesel tertinggi berasal dari tahap segar produksi biomassa tandan buah kelapa sawit (49\%-64 \%) dari total biaya. Analisis extended LCA menyimpulkan bahwa kenaikan mikroalga dan biaya produksi minyak biodiesel sawit adalah sekitar $2,6 \%$ dan $17,7 \%$. Biomassa untuk produksi biodiesel dari mikroalga relatif lebih ramah lingkungan dibandingkan dari kelapa sawit karena berbagai kendala pada penggunaan mikroalga dapat ditangani. Selain itu, mikroalga memiliki kontribusi yang signifikan dalam gas rumah kaca (GRK) mitigasi dengan mengganti bahan bakar fosil di masa depan melalui perannya sebagai biodiesel.
\end{abstract}

Kata Kunci: mikroalga, biodiesel, komoditas lingkungan, biaya produksi, LCA 


\section{PENDAHULUAN}

Indonesia di masa mendatang diprediksi akan mengalami krisis energi nasional. Krisis energi ini dipicu oleh ketidakseimbangan antara produksi dan konsumsi energi terutama energi dari bahan bakar minyak (BBM) dalam negeri. Sejak tahun 2003, produksi minyak Indonesia sudah tidak mampu lagi untuk mencukupi kebutuhan energi nasional sementara kebutuhan BBM terus meningkat. Krisis energi semakin diparah dengan kondisi komposisi pengunaan energi yang tidak seimbang yakni hampir $90 \%$ berasal dari 3 sumber energi fosil utama yaitu batu bara, minyak bumi, dan gas alam, sementara energi non-fosil (tenaga bayu, panas bumi dan matahari) serta energi dari bahan bakar nabati tidak mengalami perkembangan yang signifikan. Salah satu upaya mengurangi ketergantungan terhadap energi fosil adalah dengan mencari alternatif sumber energi yang terbarukan seperti biodiesel dari minyak sawit, jagung, jarak dan tanaman pangan lainnya [1].

Dalam rangka untuk mengurangi ketergantungan yang tinggi pada BBM tersebut, pemerintah Indonesia melakukan program konversi BBM ke bahan bakar gas (LPG-liquor petrol gas). Pada upaya yang sama, pemerintah juga telah mempromosikan upaya diversifikasi energi non BBM dengan menetapkan Peraturan Presiden No. 5/ 2006 kebijakan energi nasional. Peppres tersebut menargetkan penggunaan energi terbarukan yang di dalamnya terkandung sumber energi alternatif berupa bahan bakar berbahan nabati (BBN) seperti bioetanol, dan biodiesel sebanyak $5 \%$ pada tahun 2025. BBN biodiesel biasanya diproduksi dari bahan minyak kelapa sawit (crude palm oil_CPO), sedangkan bioetanol berasal dari bahan molase, jagung, singkong dan umbi-umbian. Asosiasi produsen biofuel Indonesia (APROBI) menyatakan bahwa total produksi tahunan biodiesel dan bioetanol Indonesia meningkat pesat dari 0,65 juta liter dan 0,194 juta liter pada tahun 2011 menjadi 0,7 juta liter dan 0,2 juta liter pada tahun 2012. Namun peningkatan produksi BBN ini masih jauh dari skema Perpres yang menargetkan pemakaian tahunan BBN biodiesel dan bioetanol pada periode tahun 2011-2015 sebesar 4,52 juta liter dan 2,78 juta liter[2]. Berbagai upaya untuk mempolerkan dan memasarkan biosolar (biodiesel) telah dilakukan yakni dengan mencampur Crude Palm Oil (CPO) dengan solar menjadi bahan bakar kendaraan, tetapi jumlahnya masih sangat terbatas. Bila campuran CPO dalam solar diperbanyak, dikhawatirkan akan mempengaruhi persediaan CPO bagi minyak goreng/bahan makanan lain. Kendala lain yang masih belum tertangani adalah struktur biaya produksi yang tergantung dengan skala produksi, struktur pasar yang belum terkonsolidasi, keterbatasan dalam infrastruktur baik untuk mengolah, maupun untuk mendistribusikan dan mengangkut biomassa, keterbatasan cara bercocok tanam, ketersediaan air, benih dan pupuk, konservasi biodiversitas serta masih terbatasnya jejaring dalam logistik dan distribusi. Selain kendala teknis di atas, upaya konversi bahan bakar nabati ternyata melahirkan perdebatan di kalangan peneliti dan pemerhati lingkungan karena kontribusi produksi biodiesel ini justru menambah emisi gas rumah kaca akibat dari perubahan penggunaan lahan [1,3], mengancam pasokan pangan, dan meningkatkan kerusakan hutan dan keanekaragaman hayati [4].

Biomassa dari alga mendapat prioritas utama sebagai salah satu bahan biodiesel. Keunggulan biomassa ini adalah karena statusnya sebagai bahan sumberenergiyang dapat diperbarui [5]yang mempunyai kemampuan terhadap pengurangan emisi gas $\mathrm{CO}_{2}$. Alga memanfaatkan sinar matahari untuk merubah $\mathrm{CO}_{2}$ menjadi karbohidrat, lemak dan protein dengan produktivitas yang jauh lebih efisien dibanding dengan tanaman darat [6]. Alga juga memiliki double time (kelipatan dua) pertumbuhan sekitar 3,5 jam, memerlukan lebih sedikit air dalam pertumbuhannya dan mampu menghasilkan bahan baku biofuel 15300 kali lebih cepat dibanding dengan tanaman darat [7]. Tingginya produktivitas alga untuk menjadi sumber bahan biofuel yang ekonomis dan ramah lingkungan telah menarik perhatian kalangan pebisnis dan peneliti. Penelitian dalam skala laboratorium dan skala pilot project tentang pemanfaatan alga sebagai bahan baku biofuel telah banyak dilakukan. Penanganan proses mulai dari pemurnian dan pemilihan galur, operasional produksi biomassa, pemanenan telah dikuasai dengan baik, namun penerapannya di lapangan untuk menjadi suatu kegiatan bisnis berskala besar masih memerlukan tahapan lanjutan yang lebih lama. Refinery biofuel dari biomassa alga masih diperdebatkan kelayakan dalam manfaat ekonomi dan ekologinya.

Penulis akan mengevaluasi dan membandingkan komposisi biaya produksi biodiesel dari biomassa mikroalga dengan biomassa kelapa sawit. Biaya yang dievaluasi meliputi total biaya produksi produksi biodiesel secara alami dan total biaya produksi biodiesel dengan memperhitungkan komponen komoditi lingkungannya.

\section{BAHAN DAN METODE}

\subsection{Penentuan Unit Fungsional}

Unit fungsional yang ditetapkan adalah 1 liter biodiesel. Unit ini akan menjadi acuan dari seluruh 
input data yang digunakan. Selain unit fungsional, pada tahap ini juga dilakukan penetapan dan penyamaan lingkup perhitungan dari masing -masing produk sasaran.

\subsection{Life Cycle Costing (LCC)}

Analisis life cycle costing adalah salah satu metode analisis ekonomi untuk menentukan seluruh biaya produksi yang dikeluarkan oleh suatu proses produksi barang mulai dari proses pemilihan/penyediaan bahan baku, instalasi peralatan produksi, kegiatan operasional, pemeliharaan alat hingga pemanfaatan akhir produk tersebut[8]. Dalam penelitian ini, seluruh biaya yang timbul dari proses produksi biodiesel minyak sawit dan minyak alga didasarkan pada komponen biaya pada sistem produksi biodiesel yang meliputi 3 tahapan yaitu produksi tandan buah segar (TBS) atau biomassa mikroalga, produksi crude palm oil (CPO)/minyak alga dan produksi biodiesel. Seluruh biaya produksi pada setiap tahapan proses diinventarisasi berdasarkan bahan baku yang digunakan, energi yang dipakai dan energi yang dihasilkan. Untuk memenuhi tingkat kesahihan data dengan skala ekonomi, maka data produksi biodiesel minyak sawit diambil dari 35 perkebunan sawit yang luasnya di atas 10.000 ha dengan masa produktif selama 15-25 tahun, sedangkan data produksi biodiesel minyak alga diambil dari 40 kegiatan produksi biodiesel alga dengan kapasitas produksi biomassa sekitar 10 - 15 ton/ha/tahun. Perbandingan komponen biaya antara biodiesel dari minyak sawit dan minyak alga didasarkan pada harga resmi biodiesel yang berlaku di pasaran Indonesia

\subsection{Penentuan Nilai Variabel Eksternalitas}

Nilai variabel eksternalitas terdiri atas biaya dan manfaat timbul dari proses produksi biodiesel yang berupa nilai lahan, nilai konflik sosial dan nilai lingkungan. Nilai lahan yang digunakan adalah lahan budidaya kelapa sawit dan wadah budidaya mikroalga yang diperhitungkan berdasarkan pendekatan harga pasar [9]. Dalam penelitian ini, peneliti menggunakan 2 macam penentuan nilai lahan yaitu: nilai lahan berdasarkan produktivitas dan nilai lahan berdasarkan nilai ekologis. Perhitungan nilai lahan berdasarkan produktivitas mengikuti formulasi yang memperhitungkan nilai ekonomi lahan, dengan rumus Cahyono et al., 2009 [10]:

$$
\mathrm{V}_{\mathrm{p}}=\Sigma\left(\mathrm{P}_{\mathrm{pi}} \cdot \mathrm{h}_{\mathrm{pi}}\right)
$$

Keterangan:

$\mathrm{Vp}=$ nilai ekonomi lahan (Rp/ha/tahun)

$\mathrm{Ppi}=$ produktivitas lahan pertanian jenis tanaman i (ton/ha/tahun) hpi = harga produk jenis tanaman i (Rp/ton)

Kegiatan budidaya mikroalga dan kelapa sawit menggunakan lahan hutan, maka formula yang digunakan adalah [10]:

$\mathrm{Vr}=\mathrm{Ph} \cdot \mathrm{hk}$

Keterangan:

$\mathrm{Vr} \quad=$ nilai ekonomi hutan (Rp/ha/tahun)

$\mathrm{Ph}=$ produktivitas hutan ( $\mathrm{m}^{3} /$ ha/tahun)

$\mathrm{hk}=$ harga jual kayu di pasaran $\left(\mathrm{Rp} / \mathrm{m}^{3}\right)$

Perhitungan nilai lahan dengan memperhitungan nilai fungsi ekologis lahan diperoleh dari perhitungan Ruitenbeek [11] dan Constanza et al.,1997 [12] yang telah disesuaikan dengan kondisi waktu pengambilan data seperti terlihat dalam Tabel 1.

Tabel 1. Nilai lahan berdasarkan substitusi fungsi ekologisnya (Rp/ha).

\begin{tabular}{lr}
\hline Parameter fungsi ekologis & \multicolumn{1}{c}{ Rp/ha } \\
\hline Produk kayu & 956.015 \\
Produk non-kayu & 1.365 .736 \\
Pengendali gangguan & 27.315 \\
Pengatur tata air & 54.629 \\
Pengendali erosi & 969.673 \\
Pembentukan lapisan & 109.259 \\
tanah & 1.092 .589 \\
Siklus hara & 1.024 .302 \\
Pemrosesan limbah & 673.323 \\
Keanekaragaman hayati & 68.287 \\
Lain-lain & 6.341 .129 \\
Total (Rp/ha) &
\end{tabular}

Sumber: Ruitenbeek, 1999[11]; Constanza et al.,1997[12] yang telah diadaptasi penulis

Biaya sosial adalah biaya yang dikeluarkan karena permasalahan sosial seperti konflik akibat pemanfaatan lahan untuk perkebunan, relokasi penduduk dan operasional produksi biodiesel. Penentuan Biaya sosial dilakukan dengan memperkirakan nilainya sebesar 0,05 \% dari semua biaya investasi untuk kelapa sawit[13], dan sekitar 0,01\% untuk mikroalga[14]. Nilai lingkungan dihitung berdasarkan biaya (nilai kerugian) akibat pencemaran udara. Nilai pencemaran udara ini dihitung dengan menggunakan perangkat lunak Environmental Priority Strategy (EPS) versi 2000 yang dirancang oleh the Centre for the environmental assessment of Product and Material systems (CPM), Swedia. Nilai komoditas lingkungan EPS didekati dengan elastisitas kemampuan membayar dari Negara / lokasi yang mengaplikasikannya[15,16]. Penyesuaian nilai komoditas lingkungan dari EPS ke nilai komoditas lingkungan Indonesia berdasarkan perbandingan 
nilai pendapatan perkapita negara Swedia dan Indonesia (Tabel 2).

WTP untuk Indonesia (WTPIna) dihitung dengan membandingkan dengan nilai WTP Uni Eropa (WTPEU) dengan menggunakan nilai pendapatan domestik perkapita (GDP):

$W T P_{I n a}=\frac{W T P_{E U} x G D P_{I n a}}{G D P_{E U}}$

Dimana GDPIna adalah US\$ 3.716 (UNDP, 2011) dan GDPEU adalah US\$ 32.700 (Silalertruksa, 2012). Nilai WTPIna diasumsikan dari nilai WTPEU yang dikalikan rasio antara GDPIna dan GDPEU

Tabel 2. Nilai komoditas lingkungan dari pembakaran setiap 1 liter biodiesel Indonesia

\begin{tabular}{llc}
\hline $\begin{array}{l}\text { Kotagori } \\
\text { komoditas } \\
\text { lingkungan }\end{array}$ & $\begin{array}{l}\text { Satuan } \\
\text { Unit }\end{array}$ & $\begin{array}{l}\text { Rp per ton } \\
\text { biodiese/* }\end{array}$ \\
\hline $\mathrm{CO}_{2}$ & $\mathrm{~kg} \mathrm{CO}_{2}$ & 434 \\
$\mathrm{CH}_{4}$ & $\mathrm{~kg} \mathrm{CH}_{4}$ & 10.744 \\
$\mathrm{~N}_{2} \mathrm{O}$ & $\mathrm{kg} \mathrm{N}_{2} \mathrm{O}$ & 151.298 \\
$\mathrm{CO}$ & $\mathrm{kg} \mathrm{CO}$ & 1.302 \\
$\mathrm{NO}_{\mathrm{x}}$ & $\mathrm{kg} \mathrm{NO}_{\mathrm{x}}$ & 8.414 \\
$\mathrm{SO}_{2}$ & $\mathrm{~kg} \mathrm{SO}_{2}$ & 12.918 \\
$\mathrm{VOC}$ & $\mathrm{kg} \mathrm{VOC}_{10}$ & 8.455 \\
$\mathrm{PM}_{10}$ & $\mathrm{~kg} \mathrm{PM}_{10}$ & 142.450 \\
\hline
\end{tabular}

*Berdasarkan nilai tukar rupiah sebesar 9.200 IDR per EUR

\subsection{Produksi Biodiesel dari Minyak Sawit}

Proses produksi biodiesel dari minyak sawit terdiri dari beberapa tahap yaitu tahap budidaya tanaman sawit, tahap produksi CPO dan tahap produksi biodiesel.

Palm cultivation: pada tahap ini terdiri atas kegiatan penumbuhan dan pembesaran tanaman sawit pada tingkat pembenihan dan tingkat pembesaran tanaman di kebun sawit. Material dan energi yang diperlukan pada tahap ini berupa lahan perkebunan, pupuk, obat-obatan herbisida/ pestisida, air dan benih sawit. Sedangkan output

yang dihasilkan adalah buah tandan segar (fresh fruit bunches, FFB) dan emisi yang berasal dari penggunaan pupuk, obat-obatan, dan mesin pertanian yang digunakan.CPO production: tahap ini terdiri atas beberapa proses antara lain:

- Pemanenan FFB

- Pemasakan dan sterilisasasi FFB

- Pemisahan empty fruit bunches (EFB), EFB selanjutnya digunakan sebagai bahan bakar:

- Ekstraksi minyak mentah

- Pemisahan decanter cake

- Pemisahan serat (fibre)

- Ekstraksi kernel menghasilkan palm kernel oil production: pada tahap ini CPO ditransesterifikasi dengan bantuan katalis sodium hidroksida $(\mathrm{NaOH})$ dan metanol.

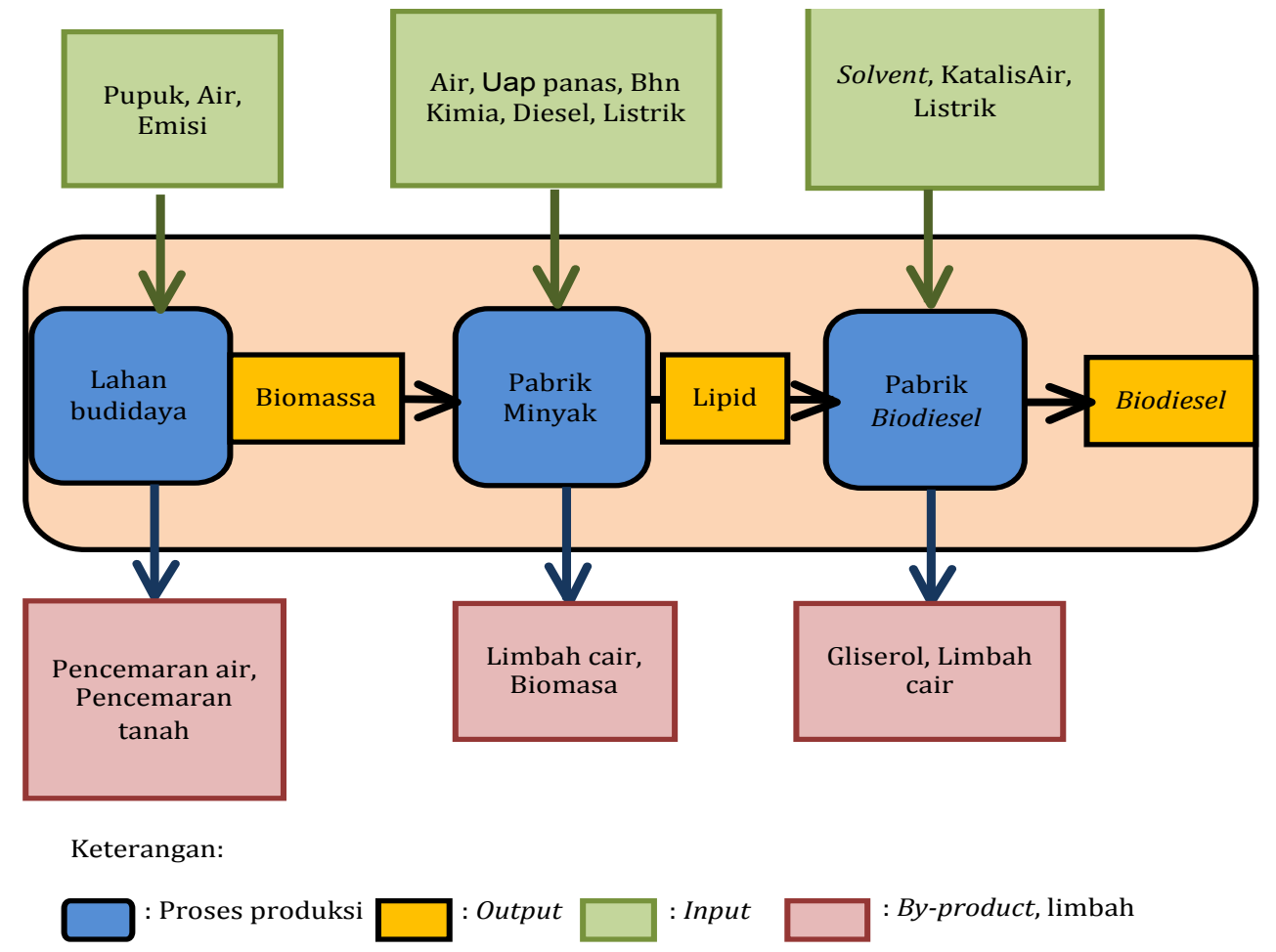

Gambar 1. Skema produksi biodiesel dari biomassa kelapa sawit dan mikroalga 
Input proses yang dibutuhkan adalah CPO, air, energi listrik dan katalis. Sedangkan output yang dihasilkan adalah palm methyl ester (biodiesel), glycerol dan limbah cair.

\subsection{Produksi Biodiesel dari Minyak Mikroalga}

Proses produksi biodiesel dari minyak alga juga terdiri 3 tahap yaitu tahap budidaya mikrolaga dalam kolam kultur atau fotobioreaktor, tahap produksi minyak alga dan tahap produksi biodiesel. Keseluruhan dari sistem produksi biodiesel dari minyak alga direpresentasikan dalam Gambar 1.

Pada tahap budidaya mikroalga, proses kegiatan yang penting adalah proses budidaya mikroalga dalam kolam atau fotobioreaktor dan proses pemanenan. Pada kegiatan budidaya, diperlukan keahlihan dalam hal mengontrol pemberian nutrien bagi mikroalga dan menjaga kondisi media agar selalu dalam konsentrasi yang ideal bagi pertumbuhan alga. Sementara pada tahap pemanenan masih terus dikaji alternatif operasional yang optimal karena pada tahap ini banyak menyerap energi. Prosep tahap produksi lipid alga dan biodiesel hampir sama dengan tahap proses produksi CPO dan biodiesel pada minyak sawit. Hal penting yang membedakannya adalah adalah adanya proses sonikasi yakni proses pemecahan dinding alga yang banyak menyerap energi dan larutan katalis.

\subsection{Penentuan Life Cycle Costing (LCC)}

Penentuan Life cycle costing dari produksi biodiesel melibatkan semua biaya yang timbul dalam produksi biodiesel minyak sawit dan minyak alga berdasar sistem produksi seperti yang ditunjukkan pada Gambar 1, yaitu produksi biomassa, produksi CPO/Lipid dan produksi biodiesel. Biaya produksi di setiap tahap dirinci seperti pada Tabel 3.

Tabel 3. Komposisi biaya produksi dan biaya eksternalitas pada produksi 1 liter biodiesel dari biomassa mikroalga dan kelapa sawit.

\begin{tabular}{|c|c|c|c|c|c|c|c|}
\hline \multirow{2}{*}{ No } & \multirow{2}{*}{ Proses/Bahan } & \multicolumn{3}{|c|}{ Mikroalga } & \multicolumn{3}{|c|}{ Kelapa sawit } \\
\hline & & $\mathrm{Rp}$ & Total & $\%$ & $\mathrm{Rp}$ & Total & $\%$ \\
\hline \multirow[t]{5}{*}{1} & \multicolumn{2}{|l|}{ Budidaya } & 5.955 & 64,08 & & 4.680 & 49,03 \\
\hline & $\begin{array}{l}\text { a. Persiapan } \\
\text { lahan/wadah }\end{array}$ & 1.367 & & & 3.023 & & \\
\hline & b. Pupuk & 778 & & & 330 & & \\
\hline & c. Bahan lain & 27 & & & 353 & & \\
\hline & d. Panen & 3.783 & & & 974 & & \\
\hline \multirow[t]{5}{*}{2} & \multicolumn{2}{|c|}{ Produksi Minyak alga/sawit } & 1.683 & 18,45 & & 1.445 & 15,14 \\
\hline & a. Metanol & 851 & & & 667 & & \\
\hline & b. Bahan lain & 163 & & & 330 & & \\
\hline & c. Energi listrik & 453 & & & 236 & & \\
\hline & d. Energi panas & 217 & & & 212 & & \\
\hline \multirow[t]{5}{*}{$\overline{3}$} & \multicolumn{2}{|l|}{ Produksi biodiesel } & 1.095 & 11,78 & & 997 & 10,45 \\
\hline & a. Metanol & 480 & & & 393 & & \\
\hline & b. Bahan lain & 63 & & & 188 & & \\
\hline & c. Energi listrik & 416 & & & 283 & & \\
\hline & d. Energi panas & 136 & & & 133 & & \\
\hline \multirow[t]{3}{*}{4} & \multicolumn{2}{|l|}{ Lain-lain } & 317 & 3,41 & & 730 & 7,65 \\
\hline & a. Pajak, dan lain-lain & 190 & & & 393 & & \\
\hline & b. Tenaga kerja & 127 & & & 338 & & \\
\hline \multirow[t]{4}{*}{5} & Eksternalitas & & 242,29 & 2,61 & & $1.692,55$ & 17,73 \\
\hline & a. Nilai lahan & 309 & & & 961 & & \\
\hline & b. Biaya lingkungan & 197 & & & 196 & & \\
\hline & c. Biaya sosial & 2 & & & 125 & & \\
\hline \multicolumn{3}{|c|}{ Total Biaya } & $9.292,29$ & 100,00 & & $9.545,55$ & 100,00 \\
\hline
\end{tabular}


Berdasarkan perbandingan komposisi biaya produksi biodiesel di atas dapat ditarik beberapa hal penting antara lain:

1. Komponen biaya terbesar terletak pada biaya pengadaan/produksi biomassa (CPO/minyak mikroalga) yang mencapai $49,03 \%$ pada kelapa sawit dan $64,08 \%$ pada mikroalga. Informasi ini memberi perhatian kepada pemerhati biofuel, bahwa untuk menyelaraskan harga biodiesel agar lebih ekonomis maka harus menekan pada biaya produksi biomassa mikroalga atau tandan buah segar (TBS) kelapa sawit ini. Penghematan biaya produksi biomassa tersebut dengan cara mengefisienkan proses persiapan lahan, dan operasional budidaya akan dapat menekan keseluruhan biaya produksi biodiesel. Pada produksi biomassa mikroalga, biaya produksi biomassa sekitar $64,08 \%$ dari total produksi atau sekitar Rp. 5.955. Untuk menekan biaya produksi biomassa ini diperlukan upaya perbaikan dan efisiensi dalam proses pemanenan mikroalga dan penghematan energi listrik dalam proses budidaya.

2. Biaya eksternalitas produksi biodiesel dari mikroalga lebih kecil yakni sekitar 2,6 $\%$ dibanding kelapa sawit yang sekitar $17,7 \%$. Informasi ini dapat menjadi pertimbangan bagi pihak-pihak penentu kebijakan energi di Indonesia. Bila CPO dipilih menjadi bahan biodiesel, maka konsekuwensinya adalah setiap liter yang diproduksi membebani lingkungan berupa pencemaran sebesar $17,7 \%$.

3. Pada produksi biodiesel dari mikroalga banyak digunakan bahan kimia, yakni metanol untuk proses esterifikasi-trans esterifikasi, bahan kimia untuk sterilisasi dan beberapa pupuk an-organik. Penggunaan bahan kimia ini perlu diwaspadai karena berpotensi mencemari lingkungan, sehingga diperlukan upaya untuk menetralkan bahan-bahan tersebut sebelum dibuang ke lingkungan atau digunakan lagi dalam siklus produksi.

\subsection{Penentuan Biaya Eksternalitas}

Biaya eksternalitas yang dihitung dan dimasukkan sebagai biaya produksi biodiesel terdiri atas tiga macam, yaitu biaya penggunaan lahan (nilai lahan), biaya lingkungan dan biaya sosial. Untuk mengetahui besarnya kontribusi variabel ekternalitas terhadap keseluruhan biaya produksi biodiesel dari biomassa kelapa sawit dan mikroalga, berikut ini disajikan perhitungan biaya produksi 1 (satu) liter biodiesel dari biomassa kelapa sawit dan mikroalga yang berasal dari perhitungan data skala komersial (Gambar 2).

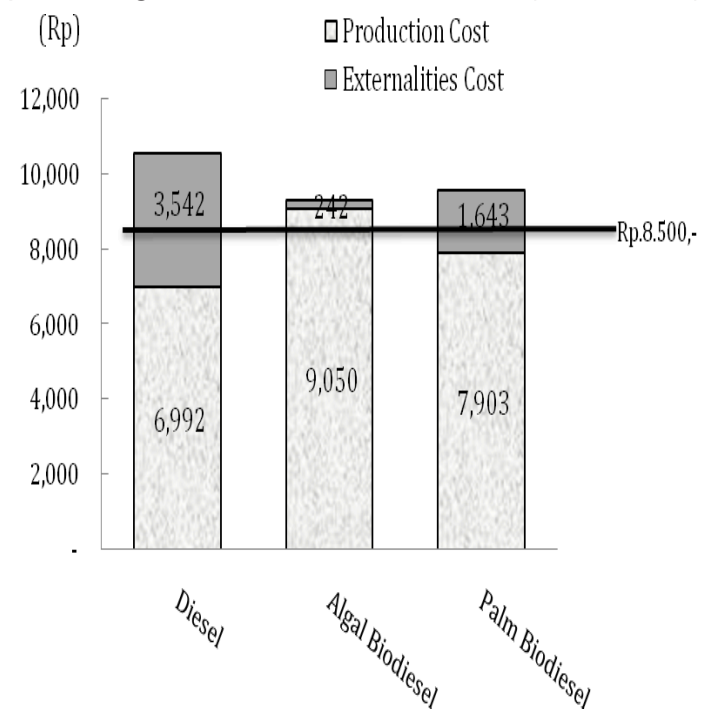

Gambar 2. Perbandingan total biaya produksi dan biaya eksternalitas dari produksi $1 \mathrm{~kg}$ diesel, biodiesel mikroalga dan biodiesel kelapa sawit.

Bila biaya produksi bahan bakar dihitung tanpa memperhitungkan biaya eksternalitas, maka produksi bahan bakar dari diesel, mikroalga dan kelapa sawit yang berkisar Rp. 6.992; Rp. 9.050,dan Rp. 7.903,- Berdasarkan ke-3 harga produksi tersebut, harga biodiesel dari mikroalga tidak memenuhi nilai profit karena biaya produksinya berada di atas harga pasaran diesel yaitu Rp. 8.500,-. Dengan hanya mengikuti harga pasar dan pasokan bahan bakar diesel selalu tersedia, maka peluang biodiesel mikroalga untuk menjadi substitusi bahan bakar fosil menjadi terhambat. Di masa depan, biaya eksternalitas yang terdiri atas biaya pengunaan lahan, biaya lingkungan dan sosial menjadi keharusan untuk dimasukkan ke dalam struktur biaya produksi barang/jasa. Penambahan biaya eksternalitas ini akan mempengaruhi total biaya produksi suatau barang/jasa. Pada produksi diesel, dengan memperhitungkan biaya eksternalitas maka biaya produksi 1 (satu) liter diesel menjadi Rp.10.534 atau naik sekitar $33,6 \%$, sedangkan untuk biaya produksi biodiesel kelapa sawit dan mikroalga masing masing naik menjadi Rp.9.546 (17,7\%) dan Rp. 9.292 (2,6 \%).

Dari analisis data di atas dapat diketahui bahwa setiap produksi biodiesel dari biomassa mikroalga menyebabkan beban lingkungan sebesar 2,6\% sedangkan dari biomassa kelapa sawit membebani lingkungan sebesar $17,7 \%$. Dalam hal ini, yang dimaksud beban lingkungan adalah meniadakan biaya perbaikan lingkungan yang seharusnya dibayar oleh produsen/konsumen karena biaya 
tersebut tidak diperhitungkan di pasaran. Beban lingkungan yang ditanggung akan semakin besar seiring dengan peningkatan produksi dan konsumsi biodesel. Konsumsi biodiesel Indonesia yang berasal dari kelapa sawit rata-rata per tahun mencapai 600.000 kilo liter per tahun [17], maka beban lingkungannya diperkirakan sekitar 2,1 trilyun per tahun. Perbandingan biaya eksternalitas dari biomassa mikroalga yang sekitar 6 kali lebih kecil dari kelapa sawit akan menjadi pertimbangan utama untuk menentukan prioritas pemilihan sumber biomassa.

\section{HASIL DAN PEMBAHASAN}

Berdasarkan uraian di atas, dapat disimpulkan bahwa variabel eksternalitas menjadi variabel kunci penyelamat lingkungan sehingga harus diperhitungan dan menjadi faktor penentu utama dalam setiap pengambil keputusan yang memanfaatkan sumber daya alam. Untuk mengaktifkan peranan variabel ekternalitas dalam perhitungan biaya produksi dan kesetimbangan energi suatu produksi biodiesel, maka variabel tersebut harus diaktualkan dalam nilai yang dapat dinilai oleh pasar.

Berdasarkan hasil analisis LCC menyatakan bahwa tingginya biaya produksi biodiesel ini disebabkan karena tingginya biaya produksi CPO/minyak alga. Harga CPO dan minyak alga mendominasi biaya produksi sekitar 51,2 \% dan $62,3 \%$, sementara biaya lain yang tinggi adalah katalis metanol sekitar $12 \%$. Informasi tingginya biaya tersebut menjadi tantangan peneliti untuk mecari alternatif teknologi yang lebih efisien dan ekonomis.

Internalisasi biaya eksternalitas pada produksi biodiesel merubah total biaya produksi biodiesel dari alga dan sawit. Penambahan biaya ekternalitas pada biaya produksi biodiesel menyebabkan kenaikan biaya produksi biodiesel sawit dan biodiesel alga masing masing sebesar $17,7 \%$ dan $2,6 \%$. Total biaya produksi biodiesel dengan menambahkan biaya ekternalitas menyebabkan harga biodiesel tidak kompetitif bila dibandingkan dengan harga BBM, sehingga untuk mendorong program konversi BBM ke biodiesel tidak hanya diperlukan subsidi tapi juga harus diterapkan strategi dengan mengangkat fungsi pentingnya eksternalitas. Sebagai ilustrasi, bila konsumsi biodiesel Indonesia yang berasal dari sawit rata-rata per tahun mencapai 600.000 kilo liter per tahun, maka beban lingkungan yang harus ditanggung oleh masyarakat diperkirakan sekitar 2,1 trilyun per tahun.

Ditinjau dari keberlanjutan pasokan biomassa untuk produksi biodiesel, maka biomassa alga lebih potensial dibanding biomassa sawit. Biomassa sawit selain terkendala dalam hal peningkatan produktivitas CPO (lahan, konflik sosial, konversi FFB ke CPO) juga terkendala adanya kompetitor penguna CPO untuk bahan pangan [4]. Di sisi lain, produksi biomassa alga memiliki potensi besar untuk dikembangkan lebih lanjut. Produksi biomassa alga tidak terbebani oleh penggunan lahan dan adanya konflik sosial. Nilai konversi biomassa alga ke minyak alga masih sangat mungkin untuk ditingkatkan dengan perlakuan pembatasan nutrien tertentu dan modifikasi penetrasi cahaya ke media budidaya[5]. Keunggulan lain dari biomassa alga adalah peranannya yang besar dalam mitigasi GRK, dimana media budidaya alga lebih banyak menyerap emisi gas GRK di banding tanaman sawit[4].

Dalam rangka untuk mendorong program konversi BBM ke biodiesel, beberapa upaya yang perlu dilakukan pemerintah Indonesia antara lain dengan meningkatkan harga biomassa lebih kompetitif dengan cara menekan biaya produksi biomassa dan memanfaatkan produk sampling yang dihasilkan. Pada produksi 1 ton biodiesel alga biasanya menghasilkan limbah berupa serat 3,12 ton dan hasil samping berupa glycerol sekitar $240 \mathrm{~kg}$. Bila harga serat biomassa alga sebesar Rp.500/kg dan harga gliserol sebesar 1,28 US\$/ $\mathrm{kg}[18]$, maka pemanfaatan limbah dan produk samping tersebut akan menghemat biaya produksi sebesar Rp.2.856/kg biodiesel. Pemanfaatan juga dapat dilakukan dengan pemanfaatan limbah seperti limbah air media budidaya dan limbah bahan kimia dengan mengolah dana memakainya lagi dalam sistem produksi dimungkinkan akan mengefisienkan biaya produksi biodiesel alga.

\section{KESIMPULAN}

Analisis LCC yang diaplikasikan dengan menambahkan variabel eksternalitas dapat memberikan informasi yang detil tentang komposisi biaya produksi biodiesel alga dan perbandingan total biaya yang ideal (environmental friendly) bila dibandingan dengan total biaya produksi biodiesel sawit dan diesel fosil. Biaya produksi biodiesel banyak terserap untuk kegiatan produksi minyak alga dan CPO yang masing-masing mencapai $62,3 \%$ dan $51,2 \%$ dari keseluruhan biaya produksi biodiesel. Informasi ini memberi pelajaran bagi pengelola usaha biodiesel, bila ingin mengefisiensikan biaya produksi harus berkonsentrasi pada tahap produksi CPO/minyak alga.

Variabel eksternalitas turut mempengaruhi total biaya produksi biodiesel hingga $17,7 \%$ dengan tiga komponen biaya terbesar meliputi biaya penggunaan lahan, pengunaan BBM dan konflik sosial.

Pasokan biomassa alga untuk produksi 
biodiesel lebih terjamin dan berkelanjutan dibandingkan biomassa sawit karena kendala teknis dan non teknis pada produksi biomassa alga lebih mudah diatasi selain itu juga keunggulan perannya dalam mitigasi GRK yang turut memperlebar peluang sebagai bahan utama biodiesel di masa depan.

\section{DAFTAR PUSTAKA}

1. Halim, R., Danquah, M.K., and Webley P.A. (2011). "Oil extraction from microalgae for biodiesel production". Biores Technol, 102. 178 - 185.

2. Kementerian Energi Sumberdaya Mineral, (2012). 2012 Handbook of Energy and economic Statistic of Indonesia.Center for Data and Information on Energy and Mineral Resources Ministry of Energy and Mineral Resources, p121

3. Demirbas, A., and Demirbas, M.F. (2011). "Importance of Algal Oil as a source of biodiesel". Energy Convers Manage, 52. 163 - 170.

4. Khoo, H.H., Tan, R.B.H., and Tan, Z.H. 2009. "GHG intensities from the life cycle of conventional fuel and biofuels". Air Pollution, 17. 329- 340.

5. orquera O., Kiperstok A., Sales E.A., Embirucu M., Ghirardi M.L. (2010). "Comparative energy life-cycle analyses of microalgal biomassa production in open ponds and photobioreactors". Bioresour Technol, 101. 1406-1413.

6. Scott, S.A., Davey, M.P., Dennis, J.S., Horst, I., Howe, C.J., Lea-Smith, D J., and Smith, A.G. (2010). Biodiesel from algae: challenges and prospects. Current Opinion in Biotecnology, 21, 227-286.

7. Chisti, Y. 2007. "Biodiesel from microalgae". Biotechnol Adv., 25. 294-306.

8. Lora, E.E.S., Palacio, J.C.E., Rocha, M.H., Renó, M.L.G., Venturini, O.J., del Olmo, O.A. (2010). "Issues to consider, existing tools and constraints in biofuels sustainability assessments. Energy". Doi:10.1016/j.energy.2010.06.012.

9. Suparmoko, M. (2009). Panduan dan Analisis Valuasi Ekonomi Sumber Daya Alam dan Lingkungan; Konsep, metode perhitungan dan aplikasi, BPFE, Edisi pertama cetakan kedua,Yogyakarta.
10. Suparmoko, M. (2009). Panduan dan Analisis Valuasi Ekonomi Sumber Daya Alam dan Lingkungan; Konsep, metode perhitungan dan aplikasi, BPFE, Edisi pertama cetakan kedua,Yogyakarta. Suparmoko, M. (2009). Panduan dan Analisis Valuasi Ekonomi Sumber Daya Alam dan Lingkungan; Konsep, metode perhitungan dan aplikasi, BPFE, Edisi pertama cetakan kedua,Yogyakarta.

11. Cahyono, S.A., Hariyadi, B., Yiliantoro, D. (2009). Nilai Guna Tak Langsung Pengelolaan DAS Grindulu. Prosiding ekspose hasil penelitian dan pengembangan. Balai Penelitian Kehutanan, Solo.

12. Ruitenbeek, J. (1999). Indonesia's Fires and Haze; the cost of catastrophe. Edited by Glover, D. and Jessup, T. Institute of Southeast Asian Studies, Singapore.

13. Constanza, R., Arge, R., Groot, R., Farber, S., Hannon, B., Limburg, K., O'neill, R. (1997). The Value of the World's Ecosystem Services and Natural Capital. Nature, 387, 253-259.

14. Manurung E.G.T. (2001). Analisis valuasi ekonomi investasi perkebunan sawit. Nature resources management program. 195 hal.

15. Nguyen, T.L.T., Gheewala, S.H., Bonnet, S. (2008). "Life cycle cost analysis of fuel ethanol produced from cassava in Thailand". Int. J. Life Cycle Assess, 13. 564-573.

16. Nguyen, T.L.T., Gheewala, S.H. (2008). "Fossil energy, environmental and cost performance of ethanol in Thailand". J. Clean. Prod, 16. 1814-1821.

17. Conner, D.O. 2001. Estimating ancillary benefits of climate policy using economywidemodels: theory and application in developing countries. Paris.

18. Hutapea, M. (2012). Direktur Bioenergi, Direktorat Jenderal Energi Baru Terbarukan dan Konservasi Energi.http://www.indonesiafinancetoday.com/ read/35907/Konsumsi-Biodiesel-Nasional -Diprediksi-Tidak-Capai-Target. Diunduh 24 November 2012 jam 17.00.

19. Pachauri N. (2006). Value-added Utilization of Crude Glycerol from Biodiesel Production: A Survey of Current Research Activities. An ASABE Meeting Presentation Paper Number: 066223. 